\title{
Markets for Technology and their Implications for Corporate Strategy
}

\author{
Ashish Arora, a Andrea Fosfuri ${ }^{b}$ and \\ Alfonso Gambardellac \\ ( ${ }^{a}$ Heinz School, Carnegie Mellon University, Pittsburgh, PA, USA, \\ ${ }^{b}$ Universidad Carlos III de Madrid, Spain and CEPR, London, UK and \\ 'Sant'Anna School of Advanced Studies, Pisa, Italy)
}

Although market transactions for technologies, ideas, knowledge or information are limited by several well-known imperfections, there is evidence that they have become more common than in the past. In this paper we analyze how the presence of markets for technology conditions the technology and corporate strategy of firms. The first and most obvious implication is that markets for technology increase the strategy space: firms can choose to license in the technology instead of developing it in-house or they can choose to license out their technology instead of (or in addition to) investing in the downstream assets needed to manufacture and commercialize the goods. The implications for management include more proactive management of intellectual property, greater attention to external monitoring of technologies, and organizational changes to support technology licensing, joint-ventures and acquisition of external technology. For entrepreneurial startups, markets for technology make a focused business model more attractive. At the industry level, markets for technology may lower barriers to entry and increase competition, with important implications for the firms' broader strategy as well.

\section{Introduction}

German chemical companies are thought to have pioneered the institutionalization of in-house $\mathrm{R} \& \mathrm{D}$ early in the 20th century, an organizational innovation that was rapidly adopted by leading firms in technology-based industries all over the world (Beer, 1959; Chandler, 1990). This model of organizing innovation, where $\mathrm{R} \& \mathrm{D}$ and the complementary assets required for innovation are integrated inside the firm, has emerged as the dominant paradigm for many decades. Indeed, it has been held up as a part of the recipe 
for lasting commercial success (e.g. Chandler, 1990). The theoretical underpinnings of this model have been examined by several authors. For instance, Nelson and Winter (1982) argue that the development of technology and innovations is based on organizational routines which are difficult to transfer across organizational boundaries. Relatedly, Teece (1988) has highlighted the transaction costs involved in transferring knowledge and technological information through arm's length market-mediated contracts.

However, in the past two decades or so there has been a rapid growth in a variety of arrangements for the exchange of technologies or technological services, ranging from $R \& D$ joint ventures and partnerships, to licensing and cross-licensing agreements, to contract R\&D. Although we lack comprehensive empirical measures over time, all the available evidence suggests that the trade in technologies has become more common than in the past (see Section 2). Recent studies have documented an increase in licensing revenues earned by US firms (Dengan, 1998) and the upsurge in patenting activities, possibly reflecting the increased opportunities for technology licensing (Hall and Ham, 1999; Kortum and Lerner, 1999). Teece himself has recently noted that under certain conditions trade in technologies is possible and likely (Grindley and Teece, 1997; Teece, 1998). In short, markets for technology are emerging and developing in several high-tech industries. ${ }^{1}$

The growth and functioning of markets for technology might be limited by several factors, most notably the tacit and context-specific nature of technological knowledge. ${ }^{2}$ However, it is undeniable that when markets for technology exist they have major implications for firms' corporate strategies. The analysis of such implications is the main goal of this paper.

Markets for technology affect the role of companies both as technology users (they can 'buy' technologies) and as technology suppliers (they can 'sell'

\footnotetext{
${ }^{1}$ This sharp distinction between markets and organizations which is made primarily for expository reasons is not completely faithful to history. Indeed, Chandler (1990) provides several examples of firms that within the in-house $\mathrm{R} \& \mathrm{D}$ paradigm have relied on external sources of knowledge. A classic reference is the reliance of DuPont on external technology until the 1930s (Hounshell and Smith, 1988). There are also important differences across sectors and countries. For instance, during the 1950s and the 1960s Japanese firms in the machinery construction and chemical industries were heavily licensing technologies, mainly from the USA (Chandler, 1990).

${ }^{2}$ Elsewhere (see Arora et al., 2001a) we study the nature and functioning of markets for technology and the factors which limit or encourage their growth (see also Pavitt, 2000). We also discuss in detail how the actions of firms, particularly early in their history, have affected the evolution of markets for technology. Sometimes companies have helped, possibly not intentionally, to develop markets for technology. For instance, this is the case of oil companies that, with their early reliance on external technological services and refining technology, have promoted the rise of specialized suppliers (Arora and Gambardella, 1998). In other industries regulation and anti-trust policy have played a major role, as for instance in technology licensing by AT\&T and IBM (Grindley and Teece, 1997). Although we acknowledge the importance of these issues, the scope of the present paper is already too broad to analyze them here.
} 
technologies). At the very least, markets for technology enlarge the strategy space: firms can choose to license in the technology instead of developing it in-house; firms can choose to license out the technology instead of (or in addition to) investing in the downstream assets needed to manufacture and commercialize the goods. Thus, for example, entrepreneurial start-ups may be able to focus more narrowly on developing technology rather than on its application, by relying on licensing and other arrangements to appropriate the returns on their innovative efforts. Given that manufacturing and commercialization require substantial resources, which smaller firms may be unable to mobilize, markets for technology may be critical for the very existence of high-tech start-ups. For technology users monitoring of externally available technologies becomes a strategic imperative, although external and internal research need not be mutually exclusive options. Moreover, markets for technology can undermine privileged access to technology that incumbent firms in an industry may enjoy, because competitors and entrants may acquire the technology from alternative sources of supply in the market. At the industry level markets for technology lower entry barriers, increase competition and compress product life cycles: all changes that require appropriate strategic responses.

This paper contributes to the literature on strategic management of technology. David Teece's seminal paper pointed out that if a firm cannot appropriate rents from innovation through licensing ('weak appropriability') in order to profit from the technology, the firm should acquire assets that are co-specialized with the innovation (Teece, 1986). Pisano (1990) argues that new product development is more likely to be internalized in those areas where the (external) R\&D market is less efficient. Iansiti (1997) claims that in a world of increasing technological options firms' competitive advantages are rooted in the ability to monitor and quickly seize the external opportunity.

A somewhat different tradition, influenced perhaps by Schumpeter's vision of even innovation becoming routine inside large firms, has emphasized the pay-off from coordinated and large scale investments. Chandler's account of commercial success has stressed the importance of complementing investments in $\mathrm{R} \& \mathrm{D}$ with coordinated investments in manufacturing and marketing (Chandler, 1990). This view, which is closely linked to the resource-based theory of the firm, stresses firm growth as a process of exploiting slack resources within the company (e.g. Penrose, 1959; Nelson and Winter, 1982; Shane, 1996). These accounts implicitly assume that such slack resources are best employed by the firm itself. In this paper we depart from the widespread premise in the technology management literature that innovations are best exploited in-house and, instead, we look at the 
implications that a well-functioning market for technology has for technology and corporate strategy. ${ }^{3}$

We begin the next section by clarifying what we mean by markets for technology and by briefly reviewing some evidence on the rise of such markets in recent years. Section 3 analyzes the consequences of 'missing' markets for intangible assets and how the behavior of companies can be affected once markets for such assets arise. Section 4 focuses on large, established firms. We discuss how some of the established technology leaders are modifying their strategies for appropriating rents from innovation by incorporating technology licensing as an important option. Section 5 examines the different challenges faced by the smaller firms, especially technology-based start-ups. Section 6 deals with the external acquisition of technology. Section 7 discusses the implications on entry and competition. Section 8 summarizes our main conclusions.

\section{Markets for Technology}

\subsection{A Tentative Definition}

In this paper we use the term 'market' in a broad sense. Strictly speaking, market transactions are arm's length, anonymous and typically involve an exchange of a good for money. Many, if not most, transactions for technology which we have observed would fail one or the other criterion. Often they involve quite detailed contracts and may be embedded in technological alliances of some sort. Thus, though we shall often paint with a broad brush, contrasting market transactions with processes inside a firm, it is not to dispute the existence of hybrid forms which characterize market transactions in technology but rather to sharpen the exposition.

The way technology is traded is linked to the peculiar nature of technology as an economic asset and as a potential object of exchange. Technology comes in very different forms and no general definition will fit. For instance, technology can take the form of 'intellectual property' (patents) or intangibles (e.g. a software program or a design) or it can be embodied in a product (e.g. a prototype or a device like a chip designed to perform certain operations) or it can take the form of technical services. We will not attempt to define technology, treating it instead as an imprecise term for useful knowledge rooted in engineering and scientific disciplines, which usually also draws from

\footnotetext{
${ }^{3}$ Granstrand (1999) also analyzes firms' strategies both as technology users and technology suppliers. Malerba and Orsenigo (2000) do discuss strategic options when technology is tradable, but argue that the conditions for making technology tradable are unlikely to be realized (see also Pavitt, 2000).
} 
TABLE 1. A Simple Typology of Markets for Technology

\begin{tabular}{lll}
\hline & Existing technology & $\begin{array}{l}\text { Future technology or } \\
\text { component for future }\end{array}$ \\
\hline $\begin{array}{l}\text { Horizontal } \\
\text { market/transactions with } \\
\text { actual or potential rivals }\end{array}$ & $\begin{array}{l}\text { Union Carbide licensing } \\
\text { Unipol polyethylene } \\
\text { technology to Huntsman }\end{array}$ & $\begin{array}{l}\text { Sun licensing Java to IBM; } \\
\text { R\&D joint ventures or other } \\
\text { technological alliances } \\
\text { between rivals }\end{array}$ \\
Vertical market/licensing to \\
non-rivals & Licensing of IP core in & $\begin{array}{l}\text { R\&D joint ventures or other } \\
\text { technological alliances; }\end{array}$ \\
& semiconductors & $\begin{array}{l}\text { Affymax licensing } \\
\text { combinatorial drug discovery } \\
\text { technology to pharmaceutical } \\
\text { companies }\end{array}$ \\
& &
\end{tabular}

practical experience from production. In turn, this means that technology transactions can take different forms, from pure licensing of well-defined intellectual property to complicated collaborative agreements, which may well include the further development of the technology or its realization 'from scratch'. ${ }^{4}$ Table 1 summarizes our definition of the market for technology in the form of a simple typology, along with canonical examples for each case.

Our definition of the market for technology is close to that proposed by the US Department of Justice in its Antitrust Guidelines for the Licensing of Intellectual Property (US Department of Justice, 1995). The US Department of Justice defines markets for technology as markets for 'intellectual property that is licensed and its close substitutes, i.e. the technologies or goods that are close enough substitutes significantly to constrain the exercise of market power with respect to the intellectual property that is licensed' (US Department of Justice, 1995, p. 6). Our definition in Table 1 also encompasses what the Department of Justice calls 'markets for innovation', which are seen as markets for 'future' technologies. These include arrangements in which the parties agree to conduct activities, jointly or independently, leading to future developments of technologies that will be exchanged (or jointly owned) among them. This is typically the market for contract $\mathrm{R} \& \mathrm{D}$ and the various types of technological alliances and joint ventures.

In sum, a market for technology refers to transactions for the use, diffusion and creation of technology. This includes transactions involving full

\footnotetext{
${ }^{4}$ Transactions in technology can also occur through mergers and acquisitions and through the mobility of people. However, given the already very broad scope of this paper, we shall ignore these cases here.
} 
technology packages (patents and other intellectual property and know-how) and patent licensing. It also includes transactions involving knowledge that is not patentable or not patented (e.g. software or the many non-patented designs and innovations).

\subsection{Some Suggestive Evidence}

Markets for technology are not a new phenomenon. Lamoreaux and Sokoloff $(1997,1998)$ have documented the existence of an active market for patents in the US during the 19th century. However, it appears that these markets declined after the 1920s and have become reinvigorated only in the last couple of decades. ${ }^{5}$ In Arora et al. (2001a) we provided rough aggregate estimates of the size and scope of markets for technology in recent decades. Using systematic data on technology transactions we found that the extent of technology trade has grown in the 1990s and high-tech industries, like software, chemicals and electronics, lead the growth of such markets (see also Merges, 1998; Anand and Khanna, 2000). Table 2 shows the total number and value (in parentheses) of such transactions, by industrial sector, between 1985 and $1997 .{ }^{6}$ The value of a transaction is calculated here as the sum of licensing and royalty payments and equity investments and $\mathrm{R} \& \mathrm{D}$ funding provided in return for licensing rights.

Table 2 shows that there have been over 15000 transactions in technology with a total value of over $\$ 330$ billion, implying an average of nearly 1150 transactions worth $\$ 27$ billion per year. To put these numbers in perspective, note that the total R\&D spending in the USA, Japan, Germany, UK, France, Italy and Canada was about $\$ 340$ billion and non-defense R\&D spending was about $\$ 300$ billion in 1995 . Thus, the value of the total technology transactions is about $9 \%$ of total non-defense R\&D spending in the developed countries. ${ }^{7}$ Although markets for technology are still in their infancy in many

${ }^{5}$ A study by the British Technology Group (1998) has concluded that most large firms in the industrialized countries have unused technologies that they have not licensed in the past but would like to do so. This points to the under-development, if not absence, of a market for technology. Supporting evidence comes from an estimate by the European Union that in Europe $\$ 20$ billion are spent every year to develop innovations and technologies that have already been developed elsewhere (see www.european-patent-office.org/patinfopro/index.htm.)

${ }^{6}$ The data are from a commercial database provided by the Securities Data Corporation (SDC), the leading commercial provider of such data. The SDC data are constructed from SEC filings (10-Qs), financial journals, news wire services, proxies and quarterly reports. We read through each transaction to verify that technology transfer was involved. From the description of the agreement we also coded the granter and the recipient of the technology or whether there was a two-way flow of technology, such as a technology cross-licensing agreement.

${ }^{7}$ There are a number of possible biases in both directions. We exclude outright acquisitions. Further, the figures for equity purchase may include payments for non-technology assets. Excluding these would 


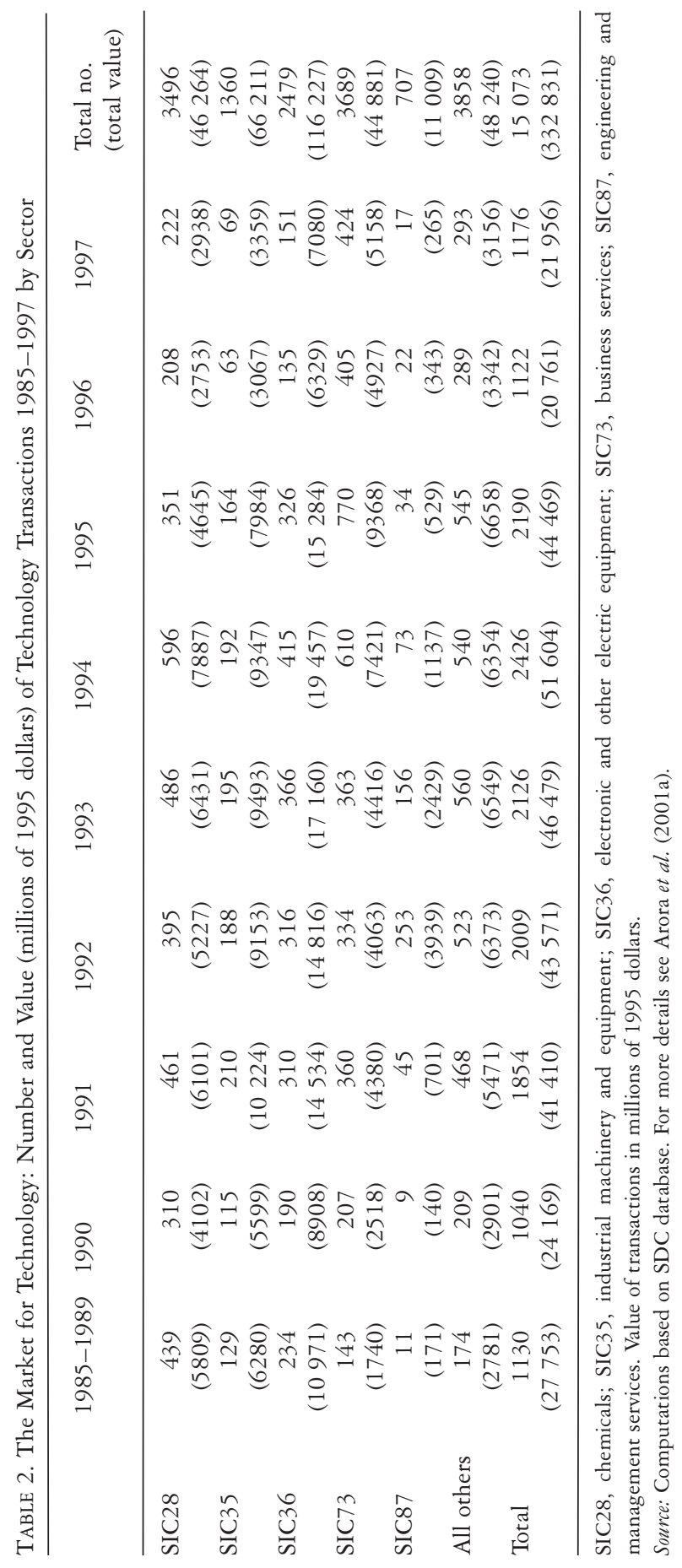


cases, the value of the transactions is already substantial. Our data also show that the number of these transactions has been steadily increasing over time, with the exception of the last two years in our sample (possibly reflecting incomplete reporting of transactions for these years).

Specific industry case studies provide possibly the most compelling evidence of the increasing importance of technology markets. The chemical industry for instance is one in which technology licensing, both products and processes, has been quite widespread for many years (see Arora and Gambardella, 1998; Arora and Fosfuri, 2000). Similarly, technology trade is becoming extensive in leading high-tech industries such as software, semiconductors and biotechnology. In semiconductors there has been a significant growth of the so-called 'fabless' or even 'chipless' companies, which specialize in the design of self-contained, independent chip 'modules' and sell their designs to other companies that design and manufacture the complex chip in which the individual modules are embedded (Linden and Somaya, 1999). Further evidence about technology trade in the semiconductor field is provided by Hall and Ham (1999), who find that licensing and cross-licensing deals have risen significantly in this industry and that the propensity to patent has increased during the last decade in response to the greater need to protect intellectual property in such deals.

\section{Markets for Technology and Corporate Strategies}

\subsection{The Effects of 'Missing' Markets for Corporate Assets}

In order to understand the implications of markets for technology for corporate strategy it is useful to begin with a more general discussion of missing markets for assets that distinguish a firm from its competitors. ${ }^{8}$ These assets include technology, production expertise and facilities, a strong brand name

reduce the value to about $\$ 15$ billion per year. On the other hand, our database probably does not include a large number of smaller value transactions and we are probably undercounting transactions from 1985-1987, as well as 1996 and 1997. Based on other studies, using IRS data on licensing and royalty fees, we estimate the value of these flows to be of the order of $\$ 50$ billion per year.

${ }^{8}$ Clearly, assets that differentiate a firm from its competitors are different from standard commodities and so also are the markets for such assets. This is particularly true for intangible assets like technology. For one, the value of such assets is driven mostly by their use value (rather than cost of production) and will therefore depend on the prospective buyer. Furthermore, intangible assets are not easy to define and delineate. This implies that the assets may be 'lumpy'; their transfer might be an all or nothing deal. In renting such assets their use is likely to be more difficult to monitor and meter (Teece, 1998). Thus, instead of speaking of the absence of markets for assets it is perhaps more accurate and realistic to speak about the efficiency of such markets and the costs of transacting in the market. The terminology of missing markets should therefore be understood as an expositional device. 
reputation, human assets, supplier networks and established marketing channels. The resource-based theory of the firm suggests that to be a source of sustained above average performance resources must meet three criteria: they must be valuable, rare and imperfectly mobile (Barney, 1991; Peteraf, 1993; Markides and Williamson, 1996). In other words, a competitive advantage must be underpinned by resources for which well-functioning markets do not or cannot exist. So, the firm builds a sustainable competitive advantage by having access to assets that its competitors cannot access. Barney (1986) notes that the possession of such assets must be rooted in imperfections in the factor market, i.e. the market where the factors used to create such assets are traded, and these imperfections ultimately arise from differences in the expectations that firms hold about the future value of the assets (Barney, 1991). Cool and Dierickx (1989) argue that not all the assets required to sustain competitive advantage can be bought and sold. Instead, such assets must be accumulated internally through a number of mechanisms over a period of time. Similarly, much of the thinking on technology strategy has approached the problem by implicitly or explicitly assuming that technological assets cannot be directly bought and sold and the services of such assets cannot be 'rented'. In this sense, our paper builds on the resource-based view of the firm by analyzing what happens when some assets that were not tradable become tradable.

What are the consequences of such a missing market for technology? The immediate consequence is that the innovator must exploit the technology in-house, ${ }^{9}$ i.e. in order to extract the value from the technology (or rather its services) it must be embodied in goods and services which are then sold. Such goods and services must have lower costs or command higher prices to deliver returns that are greater than the competitive rate of returns; firms earn 'quasi-rents'.

Consider a case where a firm has developed a new cost-reducing technology for the production of a certain good. In order to extract value from the technology the firm must use it to produce the good. Not only does this require the firm to have access to the complementary assets (such as land and physical equipment, marketing channels and so on), but the returns would also depend on the volume of output that the firm can produce and sell. If the complementary assets are themselves not traded in a competitive market or if firms differ in their access to them then firms that have superior access to these complementary assets will be able to derive greater value from the

\footnotetext{
9 This is purposely a polar characterization in which either there are markets or there are not. We acknowledge that this statement ignores a variety of 'hybrid' organizational arrangements that might be potentially used in the absence of markets. For instance, Pisano (1990) shows that the use of equity as a hostage in biotechnology research contracts can be a hybrid form to exploit research.
} 
technology. ${ }^{10}$ Similarly, firms that can exploit the technology on a bigger scale will be able to derive greater value (Cohen and Klepper, 1996; Klepper, 1996).

Following this logic further, larger firms or firms with superior access to complementary assets will have a greater incentive to invest in the technology in the first instance. Taking this one step further, firms investing in technology would be well advised to also invest in the complementary assets that cannot be easily and efficiently acquired from the market. In other words, as Teece (1986) put it, firms have to invest in creating co-specialized assets to maximize their returns from developing new technology. In sum, in the absence of a market for technology, a firm must often acquire other assets in order to extract profits from the technology. Insofar as these other assets are themselves expensive and illiquid, well-capitalized, large, integrated firms that possess such assets have greater incentives to invest in developing new technologies (Nelson, 1959). Conversely, smaller firms face major hurdles in developing and commercializing technology.

The situation is quite different when the asset can be sold or rented. Complementary assets need not be owned or even directly accessed by the technology developer. The relative importance of complementary assets within the boundaries of the individual firms diminishes compared with the existence of such complementary assets at the level of industries or markets as a whole. Clearly, as we shall also note below, transaction costs or other factors may increase the cost of acquiring the complementary assets externally compared with owning them in-house, even when such markets exist. In Arora et al. (2001a) we distinguished between cognitive factors (such as context dependence and absorptive capacity), contractual problems and other market imperfections that can limit the ability of firms to access external complementary assets. As these imperfections become less important then, to use Teece's terminology, the existence of complementary assets at the level of markets or industries may offset the lack of such assets at the level of the firm.

Ultimately, a market for the asset provides the innovator (a firm that has developed new technology) with more options. Instead of embodying a newly developed technology in goods and services a firm may choose to sell or license it to others or may choose to buy it from external providers rather than develop it in-house. This does not mean that companies would only acquire

${ }^{10}$ The literature clearly distinguishes between generic and specialized complementary assets (Teece, 1986). When the complementary assets are specialized there is an additional pressure to integration. When the complementary assets are generic it is more likely that a market for such assets will work well, providing even access to the assets to all firms. By definition, specialized or co-specialized assets face an illiquid and imperfect market. It is only when the market for complementary assets is perfectly competitive that differences across firms in the access to the complementary assets are completely leveled out. 
technologies from external sources. Leading companies would probably choose the right balance between external acquisition and in-house development of technologies, even though for companies with lower in-house technological capabilities the existence of external technology sources may be critical to enhance their ability to produce and sell more innovative goods (Iansiti and West, 1997). Similarly, a market for technology assets does not mean that innovating firms will become pure licensing companies, although several small (and not so small) firms have been successful as specialized technology suppliers. Rather, as we shall also note below, the appropriate strategy in the presence of markets for technology depends on the efficiency of markets for other types of assets, including finance. Moreover, in thinking about how a market for technology conditions strategies there is one other industry-level force that must be considered. Markets, particularly efficient markets, are great levelers. A market for technology lowers entry barriers and increases competition in the product market, which often implies a rethink of existing strategies. In turn, this implies that when there exists a wellfunctioning market for an asset such an asset cannot be a source of sustainable competitive advantage and firms have to look somewhere else to gain an edge over competitors.

\subsection{Markets for Technology and Strategies for Appropriating Rents}

Teece (1986) identifies several critical dimensions for the appropriability of the returns of firm's intellectual property: the nature of the technology, the strength of the property rights regime, complementary assets, the ease of replication and the ease of imitation. Appropriation through licensing works best when there exists a substantial gap between replication and imitation costs. If the technology is easy to replicate and transfer but difficult to imitate the innovator can capture a large part of the rents simply by licensing. Hence, when the underlying knowledge base is sufficiently codified and not contextspecific and intellectual property rights are well defined and protected, licensing can work well (Williamson, 1991; Kogut and Zander, 1993).

For instance, as discussed in Arora and Gambardella (1998), there exists a very large market for chemical processes and engineering services. The development of chemical engineering played an important role in developing more general and abstract ways of conceptualizing chemical processes. As well, patents are thought to work better in chemicals than in other industries (see for instance Levin et al., 1987; Cohen et al., 1997). In addition, many processes, especially in petrochemicals, are designed around a specific variety 
of catalyst which can be kept proprietary because of the difficulty of imitation from simple structural analysis alone. The licensor can therefore use the catalyst as a credible hostage: failure by the licensee to respect the initial agreement can trigger a cut-off in supply of the catalyst.

However, Teece (1988) argued that appropriation of the returns from innovation through licensing is the exception and not the rule. In other words, the best way of appropriating the rents from technology is by directly embodying it into goods and products. In a more recent paper Teece (1998) recognizes that the formation of markets for technology might change this view. He notes that the unbundling of intellectual property from products generates a new environment for knowledge management where the focus is on how to capture value from knowledge assets, even though he warns that $\therefore$. . becoming a pure licensing company not directly involved in the production market and increasingly remote from the manufacture and design of the product itself can be a risky strategy ...' (see Grindley and Teece, 1997). Since risk is sometimes worth the additional reward, the innovator now has the option to balance its ability to extract value from the asset by embodying it in products and services against the transaction costs involved in trading the technology. In this respect, licensing is an option not mutually exclusive with self-production. Hence, with a market for technology a firm needs to recognize what its core, non-tradable and tradable competencies are. Having done so, it can decide whether a given discovery or technological competency is to be exploited in-house or through licensing. In many instances firms might possess some 'non-core' technologies (in some cases of very substantial value) which can be profitably licensed. ${ }^{11}$

The decision on whether to exploit the technology in-house or not depends on a number of factors. First and foremost it depends on the distribution of complementary assets. If the firm has superior access to the complementary assets compared with its rivals, in-house exploitation is clearly an attractive strategy. Conversely, if the firm lacks the complementary assets it may consider selling or licensing the technology. An important special case arises when the technology in question is generic in terms of its application, such as the case of a general purpose technology. In this case only an extraordinarily large and well-diversified firm will be able to satisfactorily exploit the technology in-house. Otherwise, it is far more likely that the relevant complementary assets will be more broadly distributed, so that licensing the technology would yield higher returns.

\footnotetext{
${ }^{11}$ An anonymous referee correctly pointed out that sometimes self-production is a necessary condition for successful licensing. For instance, self-production could help assess the true value of the technology or could help identify potential bottlenecks in technology transfer. However, when there exists a well-functioning market for technology these problems are likely to be less relevant.
} 
The foregoing highlights the importance of the transaction costs involved in the markets for different types of assets. If the transaction costs of acquiring complementary assets, such as production and marketing capabilities, are lower than the transaction costs involved in selling or licensing the technology an innovator lacking the complementary capabilities may nonetheless choose to exploit its technology in-house. ${ }^{12}$ In fact, there are many factors that affect transaction costs for technology exchange. Foremost among them are well-defined and enforced property rights. Property rights are easier to define and enforce and transaction costs for technology licensing contracts are lower when the knowledge is articulatable (Winter, 1987) and can be represented in terms of general and abstract categories (Arora and Gambardella, 1994). Such representations reduce the context dependence of the technology, freeing it up to be used more generally and reducing the cognitive barriers to technology transfer (see also von Hippel, 1990, 1994).

Difficulty in valuation can significantly increase transaction costs. Accurate valuation is particularly important in cases where the firm lacks downstream assets to commercialize the technology. Current accounting practices and norms, derived as they are from times when measuring tangible and material assets was their crucial task, have to be modified in order for technology markets to flourish. This is a complex issue and a full discussion is well beyond the scope of the present paper (Deng et al., 1999; Lev and Zarowin, 1999).

What is less well understood is the role that technology markets themselves can play in improving the accounting for intangible technological assets. A market for technology improves the accuracy of any valuation attempt. It does so in the most obvious way, by providing an objective measure of the value, if the asset has been traded in the past or if similar assets have been traded. Needless to say, technology is highly differentiated and its 'price' is likely to reflect factors that are idiosyncratic to the buyer and the seller. Thus, any monetary measure is likely to be imperfect. That said, such problems are not unique to the measurement of the value of technology. A flourishing market for paintings by Old Masters, for instance, shows that product differentiation and idiosyncratic sources of value do not preclude the existence of a reasonably well-functioning market.

Moreover, when investing in $\mathrm{R} \& \mathrm{D}$ firms are implicitly making such measurements, as do investors when they value the firms in capital markets. Markets for technology allow for the possibility of valuing the contribution of technology separately from the value of other valuable assets the firm may

\footnotetext{
12 The transaction costs approach that we adopt in this paper has some well-known limitations (see Lazonick, 1991). We have discussed some of these limitations in Arora et al. (2001a).
} 
possess. In turn, such a valuation may enable firms to specialize in developing technology without necessarily having to acquire downstream capabilities.

In addition to transaction costs, the decision about in-house exploitation also depends on the extent of competition in the different markets in the 'value chain' of innovation. For instance, the innovator may face much greater competition in the product market than in the market for technology. In this case the returns from in-house exploitation are likely to be small, limited by the ability of the innovator to increase its sales and gain market share, typically a slow process. The innovator may face much less competition in the technology market and may be able to extract much higher returns there. These considerations led Qualcomm to exit from producing handsets embodying its code division multiple access (CDMA) technology and focus on technology licensing. In the early 1990s Qualcomm introduced a wireless telephone technology, based on CDMA technology, which was markedly superior to the existing technology. It embodied this technology into cellular phones (handsets) and grew rapidly, with a turnover of $\$ 4$ billion and a net income of more than $\$ 200$ million in 1999 . However, Qualcomm has decided to drastically refashion its business. Citing falling margins in the CDMA handset operations, it divested itself of manufacturing and focused on generating and licensing its CDMA technology. On an annualized basis Qualcomm earned nearly $\$ 400$ million in licensing and royalty in 1999, which is slightly more than what Qualcomm spent on R\&D in the same year (Company 8-K Report, 1999).

\section{Licensing and Related Technology Strategies by Large Firms}

\subsection{Revenue versus Rent-dissipation Effects in the Licensing Strategies of Large Firms}

The decision by a large established company of whether or not to license its technology is the result of two main forces pushing in opposite directions: the 'revenue effect' and the 'profit dissipation effect' (see Arora and Fosfuri, 1999). Licensing forces a trade-off: licensing and royalty revenues net of transaction costs (the 'revenue effect') have to be balanced against the lower price-cost margins and reduced market share that the increased competition (the 'profit dissipation effect') from the licensee implies. Although the licensor has many different strategies to limit the extent of this latter effect (for instance, the contract might impose quantity restrictions or exclusive territories or unit royalties might be fixed such as to control the licensee's 
output), an entrant is nevertheless a potential threat to the licensor's market share. This implies that firms with a large product market share (and by implication possessing the required complementary assets) are better off exploiting the technology in-house. On the other hand, if the product market share is small the firm may be able to increase profits by licensing in addition to in-house exploitation. Similarly, licensing is more attractive when the licensee operates in a different market and is unlikely to compete very strongly.

This is exemplified by the different ways in which BP Chemicals has approached acetic acid and polyethylene. In acetic acid BP Chemicals has strong proprietary technology and a substantial market share. It licenses very selectively, typically only licensing to get access to markets it would otherwise be unable to enter. In contrast, in polyethylene BP's market share is small. Although it has good proprietary technology as well, there are a dozen other sources of technology for making polyethylene. Thus BP has licensed its polyethylene technology very aggressively, competing with Union Carbide, which was the market leader in licensing polyethylene technology. Even here BP initially tried not to license in Western Europe, where it had a substantial share of polyethylene capacity. However, other licensors continued to supply technology to firms that wished to produce polyethylene in Western Europe, with the result that BP found that it was losing potential licensing revenues without any benefits in the form of restraining entry.

$\mathrm{BP}$ is not alone in choosing to appropriate rents by licensing its technology. For instance, Union Carbide is reported to have earned $\$ 300$ million from its polyolefin licensing in 1992 (Grindley and Nickerson, 1996). In 1998 IBM patent licensing revenues reached $\$ 1$ billion, or nearly $\$ 750000$ per patent, accounting for over $10 \%$ of IBM's net profits (Rivette and Kline, 1999). Texas Instruments is reported to have earned royalties of over $\$ 1.8$ billion between 1986 and 1993, a figure comparable to its cumulative net income during this period (Grindley and Teece, 1997). A number of other firms, including companies such as Dow Chemicals, Procter \& Gamble, Philips, Boeing and Monsanto, which have traditionally neither licensed their technology nor acquired technologies from the outside, have embraced technology licensing as an integral part of their technology management strategy.

Table 3 reports information from the web sites of some leading corporations wherein they advertise internal technologies available for licenses. Some of these companies have even created a special internal division that focuses on licensing of their technologies. For instance, in 1994 DuPont created the Corporate Technology Transfer Group, a division with the specific task of overseeing all technology transfer activities. 
TABle 3. Selected Web Pages Advertising the Licensing of Intellectual Property

\begin{tabular}{|c|c|c|}
\hline Company & www address & Available for licensing \\
\hline Boeing & $\begin{array}{l}\text { www.boeing.com/assocproducts/ } \\
\text { mdip/home.html }\end{array}$ & $\begin{array}{l}\text { Algorithms, laser technology and } \\
\text { manufacturing, coatings, material } \\
\text { processing, composite technologies, } \\
\text { materials, factory hand tools, } \\
\text { measurement systems, fasteners, } \\
\text { placement systems, video displays, } \\
\text { fiber optic sensors and demodulation } \\
\text { systems }\end{array}$ \\
\hline IBM & www.ibm.com/ibm/licensing & $\begin{array}{l}\text { Processes used in integrated circuits, } \\
\text { hard disk storage technology, device } \\
\text { designs, source code }\end{array}$ \\
\hline DuPont & $\begin{array}{l}\text { www.dupont.com/corp/science/ } \\
\text { technologies.html }\end{array}$ & $\begin{array}{l}\text { Fiber-related, composites, chemical } \\
\text { science and catalysis, analytical, } \\
\text { environmental, electronics, biological }\end{array}$ \\
\hline Union Carbide & $\begin{array}{l}\text { www.unioncarbide.com/business/ } \\
\text { busprgde.html }\end{array}$ & $\begin{array}{l}\text { Ethylene oxide/ethylene glycol, } \\
\text { industrial performance chemicals, } \\
\text { polyolefin resins and compounds, } \\
\text { solvents, intermediates and monomers, } \\
\text { coating materials, speciality polymers } \\
\text { and products }\end{array}$ \\
\hline Philips & www.licensing.philips.com & CD, DVD, SACD, MPEG, AC3 \\
\hline $\begin{array}{l}\text { Procter \& } \\
\text { Gamble }\end{array}$ & www.pgtechnologytransfer.com & $\begin{array}{l}\text { Procter \& Gamble online market for } \\
\text { technology }\end{array}$ \\
\hline Yet2.com & www.yet2.com & $\begin{array}{l}\text { All types of technology: an online } \\
\text { market for technology backed by } \\
\text { several large US corporations (e.g. } 3 \mathrm{M} \text {, } \\
\text { AlliedSignal, Boeing, Dow Chemical, } \\
\text { Ford, Honeywell, Polaroid, Procter \& } \\
\text { Gamble, Rockwell) }\end{array}$ \\
\hline
\end{tabular}

Recognition of the potential of the licensing market has been prompted by several related factors. First, the growing demand for technologies has increased the opportunities for selling technologies. Moreover, globalization, along with the low transportation costs of technologies, has meant that large companies with sizable technological portfolios have the opportunity to exploit their technology on a very large scale, provided they license. Second, the better functioning and the increasingly better organization of markets for technology has eased the opportunities for this type of trading. As a result, several leading large companies have recognized the opportunities for incrementing their returns on $\mathrm{R} \& \mathrm{D}$ by selling technologies rather than focusing only on their internal exploitation. Moreover, as noted above, there 
is a huge potential for this strategy, as corporations have a large share of technologies that they do not use themselves. These factors have prompted many of these companies to organize their technological portfolios and to focus more forcefully on the effective management of their technologies and intellectual capital. On the demand side increased competitive pressures and falling tariff and regulatory barriers to entry have created a large pool of potential technology buyers, firms that see their core competence not in creating technology but rather in exploiting it.

Clearly, there are many reasons why firms license, and not all of them can be ascribed to the specifics of markets for technology that we are trying to advance here. For instance, firms may license to create demand, to deter entry by stronger rivals or to dissuade rivals from launching their own R\&D projects in the area. Most importantly, in certain sectors, like electronics and software, firms may license their technology to create de facto market standards which they control and can exploit. However, the examples we have provided above illustrate the growing importance of markets for technology. They suggest that large firms are actually refocusing their technology strategy to seek additional returns from their $\mathrm{R} \& \mathrm{D}$ efforts by selling their technologies disembodied from products.

\subsection{Increasing Importance of 'Intellectual Property' Management}

The discussion above also points to the need for firms to take the management of their intellectual property seriously. Recent work by Granstrand (1999) and Rivette and Kline (1999) details how patent data can be used for competitive intelligence, to identify potential licensees, to identify potential research staff and to understand where the firm should focus its research efforts. Grindley and Teece (1997) also note that in some firms the management of intellectual property has moved from the licensing of 'non-core' technologies to become a central element in technology strategy. They recognize that in industries like semiconductors and electronics licensing and cross-licensing have become a means for generating revenues as an alternative to direct production. In turn this implies that management needs to undertake a more active and positive stance towards licensing and intellectual property in general. A related implication is that firms should be more careful about efficiently managing their intellectual property. In particular, they should identify technological areas to apply more forcefully for patent protection. Since both applying and maintaining a patent can be costly, firms might be selective in their patenting strategy. 
A recent report by ETAN (European Technology Assessment Network, 1999) on intellectual property rights highlights several new implications that the rise in technology transactions has meant for corporate strategy. The report recognizes up front that markets for technologies, ideas, knowledge and information have difficulties in operating. However, it points out that a well-defined system of protection of intellectual property can help develop a market for technological knowledge (Arora and Gambardella, 1994; Mazzoleni and Nelson, 1998; Merges, 1998; Anand and Khanna, 2000). The report stresses the importance of proactive management of intellectual property rights for both large and small firms. The creation of an intellectual property culture' in firms has become crucial and this is especially true for European firms, which are lagging behind their US and Japanese counterparts. ${ }^{13}$

Firms are still experimenting with how best to manage their intellectual assets and no single organization scheme will suit all firms. However, what is clear is that the old system of leaving patenting and licensing decisions largely under the control of the general counsel's office is likely to change drastically.

For instance, Xerox is often seen as an example of a firm that has mismanaged its intellectual property, having invented but failed to profit from a number of pathbreaking developments such as the PC and the graphical user interface. In 1997 Xerox had 8000 patents, earning only \$8.5 million in revenues, not covering even the maintenance costs. Xerox set in motion a systematic process for cataloging and evaluating its patent portfolio, pruning and giving away (often to universities) patents it did not wish to keep and monitoring the use of the rest. To guide the use of intellectual property a Xerox Intellectual Property Office (XIPO) was also set up as a separate profit center, headed by a vice president level officer reporting directly to the top management of the firm and overseeing all patent and licensing decisions. Lucent has adopted a similar structure, creating an intellectual property business unit as a profit center responsible for managing intellectual property on a corporate wide level (Rivette and Kline, 1999).

Dow Chemicals has taken a somewhat different approach. Dow used to have two people to manage its licensing business. Individual business units made their own decisions independently of each other. The recession in the early 1990s and the need to cut costs brought the over $\$ 1$ billion R\&D budget under close scrutiny. In 1994 Dow Chemicals significantly restructured

${ }^{13}$ The ETAN report also argues that a less well-understood role of patents is information sources. Indeed, although not yet routinely exploited (with the exception of chemicals and pharmaceuticals), patent databases enable access to one of the most comprehensive and accessible sources of scientific and technological information. In addition, with the new information and communication technologies this rich source of data is more easily utilized by companies and becomes a useful instrument for designing technology strategies. 
the management of its intellectual property. Each of the 29000 patents was valued and assigned to one of 15 major business units. A new structure was put in place under which intellectual property managers from each business unit would meet regularly to review patent activity on an enterprise-wide basis. Dow Chemicals now earns $\$ 125$ million in patent licensing, up from $\$ 25$ million in 1994 (Rivette and Kline, 1999).

\subsection{Corporate Venturing}

Before we move on to the analysis of technology strategies by smaller firms and start-ups, a final important technology strategy by the larger firms is corporate venturing. As Levinthal and March (1993) note, large firms, with their established routines and structures, are better suited to exploitation than exploration. In somewhat different language, large firms may be better adapted to incremental improvements of existing technologies and for commercialization of discoveries than for making new discoveries, particularly radical breakthroughs. Indeed, when such firms make a significant discovery they may not recognize or nurture it adequately, especially if the discovery is not perceived as relating to the firm's core operations and markets. Increasingly firms are spinning off these technologies as new ventures. These ventures are initially funded and managed by the parent.

Corporate venturing has increased in popularity in recent years and some believe that it may overtake venture capital as the leading source of funding for technology-based start-ups. Chesbrough (2000) compares corporate venturing with venture capital. The advantages of corporate venturing include the ability to provide more 'patient' capital and the ability to leverage complementary co-specialized assets. A significant potential advantage of corporate venturing is the ability to learn from failures. However, corporate venturing has its disadvantages compared with independent start-ups. These disadvantages include delays in decision making and the less high powered incentives given to managers. Many firms see this as a way of earning high financial returns as well as accomplishing strategic objectives. A full discussion of corporate venturing is beyond the scope of this paper. None theless, it does appear that corporate venturing, a compromise between in-house development and an entrepreneurial start-up, has thus far met with only limited success. It appears to work best when there are strong strategic links between the venture and the parent (Chesbrough, 2000). Moreover, corporate venturing is too heavily dependent on the availability of slack financial resources. With increasing capital market pressures such slack 
resources are less likely to be found than in the past. Thus corporate venturing is unlikely to always substitute for trading technology.

\section{The Different Challenges Faced by Smaller Firms}

Smaller firms face a different set of trade-offs from established large corporations in choosing between licensing and self-exploitation. Typically small firms, particularly technology-based start-ups, have to acquire the complementary assets should they choose to exploit their innovation by commercializing it themselves. For start-ups the choice often amounts to a fundamental choice of the business model itself. ${ }^{14}$ The choice depends not only on the efficiency of a market for technology but also on the efficiency of the markets for the complementary assets. In other words, in deciding how to exploit their technology small firms and start-ups must trade off the costs of acquiring capital and building in-house production, distribution and marketing capability against the rents that would be lost or shared with their partners in a licensing deal.

A commonplace about technology licensing, particularly from the perspective of small firms, is that the technology owner does not get the full return from the technology (see for example Caves et al., 1983). There are two main reasons for the failure of innovators to capture more fully the rents from innovation: inefficiency of contracts for technology and differences in bargaining power. A related potential problem is that with a royalty-based contract the innovator's earnings depend on the effort and investment that its licensees make in commercializing the technology. Thus the firm is unable to control its own fate, increasing the chances of failure. For instance, Rambus, which developed a highly successful architectural interface that speeds up data transfer, depends critically upon manufacturers of semiconductor devices, notably Intel, for its survival. ${ }^{15}$ In many instances this leads entrepreneurs to adopt a strategy whereby they try to acquire the complementary assets themselves to avoid having to share rents.

There are some potential pitfalls in such a strategy. The obvious one is that small firms also have limited bargaining power when it comes to acquiring

\footnotetext{
${ }^{14}$ Although many start-ups adopt a business model whereby they begin by licensing technology and doing contract research for others and use those earnings to acquire the required complementary assets.

${ }^{15}$ Rambus licenses its technology to all firms that make microprocessors, DRAMS, ASICS or PC controllers and chip sets. Rambus does not itself produce any semiconductor devices. It lacks any special advantage in the manufacture of semiconductor devices, which requires large investments in fabrication facilities in addition to a great deal of tacit knowledge. By not producing any semiconductor device Rambus also steers clear of any potential conflict of interests and avoids competing with its customers.
} 
capital required to build or acquire the complementary assets they need to exploit the technology themselves. Further, to the extent that many of the complementary assets are themselves not readily accessible through a market mechanism and to the extent that the entrepreneurial start-up may not be very efficient at building those assets in-house, in-house exploitation is probably a much riskier and possibly less efficient strategy.

As with the market for technology, the markets for the other assets are also developing. The clearest example is the tremendous growth in angel and venture capital. The great success that small start-ups have had in attracting financing through the equity market has also reduced the cost of both technology development and acquiring some of the complementary assets. ${ }^{16}$ Another example is the growth of merchant fabricators in semiconductors, such as TSCM and several such firms, which are developing for instance in countries like Taiwan. These firms have invested in large semiconductor foundries and manufacture application-specific integrated circuits (ASICs) and other types of semiconductor devices for other firms. A start-up firm that has developed new semiconductor technology can outsource production to a foundry and market its devices itself by developing a marketing and distribution organization. Whether it ought to develop a marketing organization or appropriate the rents from its technology through licensing the technology to others depends in part on whether it is likely to be able to develop and manage a marketing operation efficiently.

As the case of Cambridge Display Technologies (CDT) indicates, an innovative start-up firm often may not be able to manage downstream activities efficiently. CDT, a Cambridge University spin-off in Britain, specializes in conjugated polymer technologies, with light-emitting polymers being a key application. This can lead to the production of light-emitting plastics for application in a wide range of businesses, from calculators, cellular phones and similar displays to laptop computer screens.

When the technology was first developed in the early 1990s the CTD founders, mainly Cambridge University researchers, tried to develop and manufacture the technology. The result was that the company nearly went bankrupt. When professional managers were brought in they changed the business model so that the key CTD business is to license the technology to established manufacturers. CDT has entered into licensing and co-development and manufacturing deals with companies like Philips Electronics,

\footnotetext{
${ }^{16}$ For instance, Amazon, the online bookseller, is now investing large sums in building warehouses and distribution centers. An alternative strategy could have been to ally with a firm with a large distribution network, such as Kmart.
} 
Seiko-Epson, Hoechst and DuPont. This recognizes that although CDT has world leading ability in the light-emitting polymers area it does not have the developed manufacturing and marketing skills which are also essential to be a world class display manufacturer. Through licensing out patents and performing technology transfer CDT can enable its partners to apply their complementary skills to the technology to develop specific products for their markets.

There are other important considerations involved that militate against self-exploitation as well. Even if the firm can develop and manage the complementary assets efficiently, these assets may be much longer lived than the technology itself. This puts the innovator in the position of having to develop new technologies to 'feed' these complementary assets. Failing which, the firm will be left with an under-utilized manufacturing facility or marketing network. Unless these assets, or their services, can be traded on the market, at least a part of the value of these assets will be lost.

The case of Syntex illustrates the risk involved when an innovative firm chooses to build up firm-specific complementary assets to exploit an innovation in-house. Syntex was founded in 1944 in Mexico City and relocated 20 years later to Palo Alto, CA. During the early 1980s the firm became extremely successful thanks to a non-steroidal anti-inflammatory drug based on the compound naproxen (Naprosyn), first marketed in 1976. In 1981 Syntex listed on the New York Stock Exchange and in 1987 it reached $\$ 1$ billion in annual sales. However, when the patents on Naprosyn expired in 1993 and generic products started to flood the market Syntex became financially distressed. Its stock price plummeted from $\$ 54$ a share in January 1992 to \$18 a share 18 months later. In late 1993 Roche Holdings, the Swiss pharmaceutical firm, acquired Syntex in a deal valued at more than $\$ 5$ billion. Syntex's operations in Palo Alto, after some restructuring, were transformed into a research facility with support and strategic marketing planning staff.

The proximate cause of Syntex' failure was its inability to discover a new blockbuster when the patents on Naprosyn expired. Indeed, Syntex's strong research abilities notwithstanding, pharmaceutical innovations still depend a great deal upon serendipity. Bad luck associated with large fixed costs led Syntex into a huge financial distress which triggered the acquisition by Roche.

Leaving aside the question of whether Syntex's research productivity had declined, consider the role of the business model. Had Syntex not built up a substantial downstream manufacturing and marketing capability it might have been able to ride out the lean periods, because it would not have had to find the revenues to support its downstream operations. Moreover, this business model also implied that Syntex had to invest in extremely costly drug 
development and clinical trials to find its potential blockbuster drugs. The problem is not that Syntex had to exit the market. Had Syntex failed because its research ceased to be productive exit would be both privately and socially desirable. Syntex's research capability continued to be valuable, as evidenced by how Roche repositioned Syntex after the acquisition. In sum, the problem was that Syntex failed as a pharmaceutical firm, destroying some of the value of the downstream assets that it had invested in. Put differently, even if integration did not hurt its research productivity, the failure of research destroyed the value of the Syntex brand name plus the value (partially) of other firm-specific assets that Syntex had built up. ${ }^{17}$

Finally, and perhaps most important from a long-term perspective, integration may reduce the innovative potential of the firm, because acquisition of the complementary assets inevitably increases the size of firms and induces important changes in the culture of the firm and in the speed and fluidity of information flows. As Levinthal and March (1993) note, organizations divide attention and resources between two broad groups of activities. They engage in the pursuit of new knowledge, exploration, and the use and development of what is known, exploitation. Although not identical, exploration is similar to the notion of research and development, while exploitation is closer to the more downstream activities of production and marketing. A blend of exploration and exploitation is desirable (March, 1991; Levinthal and March, 1993), but dynamics within organizations may lead exploitation to drive out exploration. For instance, learning processes driven by experience, as is typically the case in manufacturing and marketing, tend to favor exploitation, because exploitation provides clearer, earlier and closer feedback (Levinthal and March, 1993).

These dynamics are hard to resist in larger organizations. Large organizations are unable to provide high powered incentives for exploration. Contrast that with the incentives that the threat of bankruptcy and stock options provide for exploration in small start-ups. Further, as Stiglitz and Weiss (1981) have demonstrated, limited liability implies that smaller organizations, with fewer fixed assets at stake, will be willing to undertake more risks. Large organizations can try to encourage exploration by forming and nurturing small subunits that are isolated from the rest of the organization. As noted earlier, such 'corporate ventures' have inherent limitations. The

${ }^{17}$ An anonymous referee raised the question of whether Syntex could have tried to 'rent' its fixed complementary assets to stave off the crisis. Although marketing agreements, which in effect amount to one partner 'renting' its marketing asset to the other partner, are known to take place in the pharmaceutical industry, we can only surmise that Syntex's marketing and production capabilities were not sufficiently attractive to potential renters. Indeed, financial stability, threatened by the failure to replace Naproysn, would appear to be a sina qua non in a marketing or production partner. 
available evidence on their performance, summarized in Chesbrough (2000), is mixed. Levinthal and March (1993) also note that corporate ventures tend to yield modest returns. In sum, there are reasons to believe that as a research-intensive company converts itself into an integrated firm, with in-house manufacturing and marketing units, its research productivity is likely to decline. ${ }^{18}$

\section{The External Acquisition of Technology and the 'Not Invented Here' Syndrome}

Markets for technology also affect the firm in its role as a user of technology. The strategic imperative is not only to maximize the revenues from the firm's actual stock of technologies but also to identify technologies that are available at a reasonable price and that will increase the value of existing assets (Iansiti, 1997; Insiti and West, 1997). This does not imply that firms can simply rely on outside technologies and need not invest in R\&D themselves. Evaluating technologies and being able to use them requires substantial in-house scientific and technological expertise (Cohen and Levinthal, 1989; Arora and Gambardella, 1994). As Mowery (1984) has pointed out, a firm is far better equipped to absorb the output of external R\&D if it is also performing some $\mathrm{R} \& \mathrm{D}$ internally. A related but different interpretation of this is provided by Gans and Stern (2000), who argue that technology buyers need to invest in $\mathrm{R} \& \mathrm{D}$ to strengthen their bargaining position in licensing negotiations. In short, internal and external R\&D are complements, not substitutes.

The ability of the firm to evaluate and use outside technology may be conditioned by its existing organizational structure, which limits information flows and how opportunities are framed (e.g. Henderson and Clark, 1990). Sometimes firms tend to disregard external technology options completely. The 'not invented here' syndrome often has legitimate roots, as corporations attempt to instill pride in the achievements of their researchers. It may also serve to motivate the firm's researchers. Rotemberg and Saloner (1994) developed a model in which a 'not invented here' type of corporate culture may serve a valuable role of committing the corporation to develop the technologies invented by the firm's in-house R\&D departments, thereby providing the appropriate incentives to the researchers. However, in a world

\footnotetext{
${ }^{18}$ As against this, Kline and Rosernberg (1986) explain in their chain-link model of innovation that these assets may provide valuable feedback to research about customer preferences and manufacturing trade-offs, thereby making the research process economically more valuable. The chain-link model seems to be a very good model for understanding the great success Japanese firms such as Toyota and Sony have enjoyed. Nonetheless, there is a definite opportunity cost to such a tight coupling between the various parts of the innovation chain, in the form of greater emphasis on exploitation at the cost of exploration.
} 
where $R \& D$ capabilities are widely diffused such a commitment device is likely to be very costly.

Markets for technology increase the penalty of the 'not invented here' syndrome. In the first place, the wide diffusion of new technology producers (other firms, smaller technology suppliers, universities, etc.) makes $\mathrm{R} \& \mathrm{D}$ duplications likely. Even in a specialized field several research units may be working on similar problems or there could be units that have already solved problems that other units are facing. By relying only on internally developed solutions companies can end up 'reinventing the wheel'.

This also points to the importance of systematic monitoring of external technological developments on a world wide basis. By using and building upon basic or generic technologies developed elsewhere companies can focus on developing specialized applications that better suit the needs of their local markets (Iansiti and West, 1997). 'Global' markets for technology can improve the innovation potential and the competitiveness of companies in technologically and possibly economically less dynamic regions. These markets permit an effective division of labor between technology producers located in areas that are more efficient in the production of technology and local producers, who have greater comparative advantages in understanding the needs of their customers. Thus chemical producers in developing countries can rely upon firms in developed countries to provide both technology and know-how and focus on ways to source raw materials and on developing the market for the products (Arora et al., 2001b).

This is particularly true with general purpose technologies (GPTs) and when there exists a market for these technologies. Under such conditions it pays the individual firms to buy the GPT and focus on customization of the technology, rather than developing the whole technology or innovation from scratch. For instance, firms in developing countries can specialize in adapting the GPT to their markets and therefore rely on their non-tradable knowledge of local demand, norms and regulations. A similar argument can be made across industries rather than across countries. Notably, it pays firms to use GPTs from leading GPT industries and customize them for their own sectors, markets or clients, rather than developing their own industry-specific technology.

To summarize, there are at least two main implications of markets for technology for companies as users of technology. First, markets for technology point to the growing importance of strategies based on monitoring external technological developments. As argued by Cohen and Levinthal (1989), this also means that companies have to develop adequate internal technological capabilities because greater internal technological skills are typically associated with greater ability to take advantage of outside technological 
developments. Second, markets for technology can make it more efficient to 'customize' products and technologies. Thus if basic technologies can be made available to a larger number of competitors in an industry, the sources of competitive advantages move downstream. This explains why several companies are increasing the 'service content' of their products. Services bundled with products can be thought of as solutions to problems that customers have, rather in the way systems integrators like IBM or Anderson Consulting provide solutions to business problems rather than selling computers or software.

\section{Industry-level Effects: Vertical Specialization, Entry and Competition}

At the industry level markets for technology can potentially give rise to significant industry-wide economies of specialization in the production of technology, especially if they encourage the formation of specialized technology suppliers. Markets for technology may then provide the downstream industries with the classical Smithian and Stiglerian advantages of division of labor.

The story of the specialized engineering firms (SEFs) in chemical processing is a natural example (see Arora and Gambardella, 1998). SEFs are firms specializing in the design, engineering and construction of chemical plants. Although some of them were founded as early as the 1920s, SEFs arose in the aftermath of World War II following the rapid growth of demand for chemical products. SEFs reaped the advantages of specialization. By working for many clients they benefited from learning by doing and by repeatedly selling their expertise (through licenses or engineering services) they could spread the cost of accumulating that expertise over a larger output. As with any division of labor, the advantages of vertical specialization then translated into greater efficiency in the downstream industry as well (see also Freeman, 1968). Over time the advantages that SEFs enjoyed in design and construction of certain types of chemical plants made them the preferred source for such services. In many cases SEFs also provided in-house proprietary technology, often on very attractive terms. This reinforces our earlier point that when markets for technology exist the penalties from not monitoring the opportunities that are created by them or from not using these markets or, even worse, from persisting with the 'not invented here' syndrome can be substantial.

Merges (1998) provides a number of examples of other types of firms that might be thought of as the SEFs of the pharmaceutical and fine chemicals industry. Firms such as Catalytica, ChemDesign and SepraChem are leveraging research and their expertise in asymmetrical synthesis to develop new 
processes for the production of pharmaceuticals and key pharmaceutical intermediates. These firms both develop proprietary technologies and either license them to pharmaceutical and specialty chemical companies or enter into alliances to supply the latter with purer and better inputs. Interestingly, Merges (1998) also notes that this trend has induced some established producers to spin-off units to provide contracted process development and manufacturing services to the pharmaceutical industry.

Markets for technology lower barriers to entry, especially when they give rise to an industry of specialized technology suppliers. For instance, while SEFs originated as an American phenomenon, during the 1950s and the 1960s US SEFs became a source of technology for the European and Japanese chemical industries. This enabled the European and Japanese chemical producers to rise and grow and to compete with US chemical companies in the international market. Similarly, SEFs from the advanced countries nowadays supply technologies to chemical producers in less developed countries and these companies compete with the chemical industry of the First World in the developing country markets, largely thanks to the availability of Western technologies (Arora et al., 2001b). ${ }^{19}$ More generally, in the international context markets for technology can lead to a dramatic shortening of product life cycles. ${ }^{20}$

The example also highlights a closely related point. Markets for technology may reduce the importance of technology as a source of competitive advantages. The point is not that technological superiority in chemical processing is unimportant. Technologically less sophisticated chemical companies (such as those in the developing countries) were likely to be less effective in taking advantage of the SEF technologies and gaps between technologically advanced and less advanced firms (or countries) did not disappear. However, the presence of the SEFs meant that this gap was reduced and the entry by newcomer chemical firms with no significant technological expertise became possible. Thus many firms have exited products which they innovated and in which they have had a great deal of experience in production. ${ }^{21}$

\footnotetext{
${ }_{19}$ Partly as a consequence, the share of industrialized countries in world chemical production has fallen dramatically from $85.7 \%$ in 1954 to $62.1 \%$ in 1994 . This is not simply a reflection of economic growth elsewhere. The share of industrialized countries in world exports of chemicals has fallen from over $97 \%$ in 1955 to less than $67 \%$ in 1993 (Eichengreen, 1998).

${ }^{20}$ The pattern just described is not different in several high-tech industries today. Specialized suppliers in biotechnology, software or semiconductors accrue typical advantages of specialization in their areas of technological expertise. Moreover, while many of these specialized technology suppliers originated in the USA and they are still largely US based, their services and technology are available to European and Japanese companies as well, which have entered into a number of licensing agreements and other types of alliances with US technology-based firms.

${ }^{21}$ For instance, ICI, which first commercialized polyethylene and polyester, has virtually exited from these markets (Arora and Gambardella, 1998).
} 
One natural response to the increase in competition produced by markets for technology is that firms have to cut costs, possibly by exiting businesses in which they lack a clear source of advantage. To the extent that technology becomes a relatively less important source of competitive advantages, another response is that firms have to look for other distinctive competitive assets. ${ }^{22}$ Indeed, as we discussed in Section 3.1, the resource-based theory of the firm argues that a competitive advantage is sustainable only if it is underpinned by resources and capabilities which are scarce and imperfectly mobile. This is for instance why detailed knowledge of the specificities of demand can become increasingly important. In turn this means that companies should focus on knowledge and information about the local geographic markets in which they operate or about the peculiar and diverse demands of their clients and users. And they have to make significant investments in capturing information about customer needs or the special requirements of their local markets (Porter, 1998).

The heterogeneity of demand is a potential source of distinctive capabilities (Teece et al., 1997). In the first place, demand heterogeneity implies that companies can extract greater value from their customers by specifying products or services that better suit their special requirements. At the same time, customers are often unable to articulate their needs in ways that can be readily transferred to the producing firms. As a result, this information can only be acquired through close relationships with them. Put simply, while knowledge about basic technologies could circulate to a greater extent, the tacit component of the knowledge bases in industry may shift towards information and expertise about what the individual customers want (von Hippel, 1998). This information is less tradable and therefore it is likely to become a prominent source of competitive advantages. In short, with markets for technology companies could take advantage of the lower cost of acquiring technologies and focus on a combination of internal and external technologies to provide distinct solutions to their markets, customers and users. This has to be based on a solid understanding of their needs, along with substantial investments in relationships with their customers and markets. ${ }^{23}$

The dynamic response rests on the recognition that in a rapidly moving

${ }^{22}$ For example, since the 1950s the chemical companies have paid significant attention to product differentiation by developing a range of different grades of their materials to suit the specific requirements of different markets or users. Similarly, control of the production of basic feedstock, through direct investments in oil producing countries, has been for many years a relatively more important source of competitive advantages than technology for the leading oil and petrochemical manufacturers.

${ }^{23}$ Porter (1998) argues that, apart from the customers, companies should make substantial investments in developing tight linkages with the wide set of resources and infrastructures of the individual regions in which they operate commercially. 
environment any sort of competitive advantage or distinctive ability of the company is unlikely to persist for a long time. Thus firms have to learn how to manage themselves in an environment in which the rate of innovation is high, competition is more intense and the time to market new products has to be shorter. Dynamic competitive advantages imply that companies have to learn how to reorganize themselves rapidly and continuously deploy new competitive advantages and distinctive assets. Specifically, as markets for technology develop, technological superiority is increasingly going to be meaningless if intended as a long-term advantage from controlling a given set of technologies. In contrast, it can become a critical source of distinctive assets if the company is capable of accumulating technological capabilities in a certain domain and continuously develop new technologies in that field by building on cumulative expertise in that area. Moreover, markets for technology could further enhance the returns on these capabilities, as companies may become leading suppliers in these markets as well.

\section{Conclusions}

There is growing evidence that trade in technology has become an important phenomenon in recent years. This paper has analyzed how markets for technology affect and condition technology strategies of companies, both as technology users and as technology suppliers. In the former case, as far as it concerns large technology-based firms, the first and most obvious implication is that markets for technology increase the strategy space and firms can choose to license their technology rather than only rely on internal exploitation. The licensing decision is driven by the interplay of the profit dissipation effect from licensing which comes through increased competition and the revenue effect from licensing which is due to the pecuniary compensation paid by the licensee for access to the technology. Accordingly, licensing is more likely to be chosen in a distant market (where it is costly to produce), when the market share of the licensor is small (e.g. 'orphan' technologies) and when the downstream market is highly competitive (as profit dissipation from an additional player is small). In addition, markets for technology prompt effective internal management and organization of companies' intellectual property.

For small firms and technology-based start-ups markets for technology increase the effectiveness of strategies based on the specialization of such firms in technology development. They do not need to incur costly and risky investments in downstream assets and can profit from their research even if they 
lack the complementary assets or if the markets for such assets are underdeveloped.

Since markets for technology also involve firms as technology buyers, the growth of such markets increases the importance of external monitoring of technological developments and it increases the penalty of insularity and the 'not invented here' syndrome. Markets for technology can also reduce the relative importance of technology as a source of distinctive advantage, because the advantage of possessing some critical knowledge or technology may be limited by the ability of competitors to acquire the technology from other sources. The natural consequence is that companies have to focus on other internal assets that may provide them with distinctive advantages. Detailed knowledge and information about the idiosyncratic needs and characteristics of specific markets and buyers is an obvious candidate. Thus markets for technology may actually increase the importance of downstream strategies for differentiation. At an industry level markets for technology lower entry barriers, increase competition and compress product life cycles: all changes that require appropriate strategic responses.

\section{Acknowledgements}

We would like to thank Henry Cheesbrough, Robert Merges, Luigi Orsenigo, Keith Pavitt, Andrea Prencipe, Eric von Hippel, two anonymous reviewers and seminar participants at the Stern Business School and University of Goteborg for helpful comments and suggestions on an earlier draft. Fabrizio Cesaroni provided valuable research assistance. The usual disclaimer applies.

\section{References}

Anand, B. and T. Khanna (2000), 'The Structure of Licensing Contracts,' Journal of Industrial Economics, 48(1), $103-135$.

Arora, A. and A. Fosfuri (1999), 'Licensing the Market for Technology,' CEPR Discussion Paper 2284. London.

Arora, A. and A. Fosfuri (2000), 'The Market for Technology in the Chemical Industry: Causes and Consequences,' Revue d'Economíe Industrielle, 92, 317-334.

Arora, A. and A. Gambardella (1994), 'The Changing Technology of Technological Change: General and Abstract Knowledge and the Division of Innovative Labour,' Research Policy, 23, 523-532.

Arora, A. and A. Gambardella (1998), 'Evolution of Industry Structure in the Chemical Industry,' in A. Arora, R. Landau and N. Rosenberg (eds), Chemicals and Long Term Economic Growth. John Wiley: New York.

Arora, A., A. Fosfuri and A. Gambardella (2001a), Markets for Technology: The Economics of Innovation and Corporate Strategy. MIT Press: Cambridge, MA. 
Arora, A., A. Fosfuri and A. Gambardella (2001b), 'Specialized Technology Suppliers, International Spillovers and Investment: Evidence from the Chemical Industry,' Journal of Development Economics, 65(1), 31-54.

Barney, J. B. (1986), 'Strategic Factor Markets: Expectations, Luck and Business Strategy,' Management Science, 32(10), 1231-1241.

Barney, J. B. (1991), 'Firms Resources and Sustained Competitive Advantage,' Journal of Management, 17, 99-120.

Beer, J. J. (1959), The Emergence of the German Dye Industry. University of Illinois Press: Urbana, IL.

British Technology Group (1998), www.btgplc.com.

Caves, R., H. Crookel and J. P. Killing (1983), 'The Imperfect Market for Technology Licensing,' Oxford Bulletin of Economics and Statistics, 45(3), 249-267.

Chandler, A. (1990), Scale and Scope: The Dynamics of Industrial Capitalism. Belknap Press: Cambridge, MA.

Chesbrough, H. (2000), 'Designing Corporate Ventures in the Shadow of Private Venture Capital,' California Management Review, in press.

Cohen, W. and S. Klepper (1996), 'Firm Size and the Nature of Innovation Within Industries: The Case of Process and Product R\&D,' Review of Economics and Statistics, 78(2), 232-243.

Cohen, W. and D. Levinthal (1989), 'Innovation and Learning: The Two Faces of R\&D,' Economic Journal, 99, 569-596.

Cohen, W. M, R. R. Nelson and J. Walsh (1997), 'Appropriability Conditions and Why Firms Patent and Why They Do Not in the U.S. Manufacturing Sector,' Working Paper, Carnegie Mellon University.

Cool, K. and I. Dierickx (1989), 'Asset Stock Accumulation and Sustainability of Competitive Advantage,' Management Science, 35(12), 1504-1513.

Deng, Z., B. Lev and F. Narin (1999), 'Science and Technology as Predictors of Stock Performance,' Financial Analysts Journal, May/June, 20-32.

Dengan, S. A. (1998), 'The Licensing Payoff from U.S. R\&D,' Journal of the Licensing Executives Society International, 33(4), 1-8.

Eichengreen, B. (1998), 'Monetary, Fiscal, and Trade Policies in the Development of the Chemical Industry,' in A. Arora, R. Landau and N. Rosenberg (eds), Chemicals and Long Run Economic Growth. John Wiley: New York.

European Technology Assessment Network (1999), Strategic Dimensions of Intellectual Property Rights in the Context of SET Policy, European Commission Report EUR 18914. European Commission: Luxembourg.

Freeman, C. (1968), 'Chemical Process Plant: Innovation and the World Market,' National Institute Economic Review, 45, 29-51.

Gans, J. and S. Stern (2000), 'Incumbency and R\&D Incentives: Licensing the Gale of Creative Destruction,' Journal of Economics and Management Strategy, in press.

Granstrand, O. (1999), The Economics and Management of Intellectual Property. Edward Elgar: Cheltenham.

Grindley, P. C. and J. Nickerson (1996), 'Licensing and Business Strategy in the Chemical Industry,' in R. Parr and P. Sullivan (eds), Technology Licensing: Corporate Strategies for Maximizing Value. John Wiley: New York.

Grindley, P. C. and D. J. Teece (1997), 'Licensing and Cross-Licensing in Semiconductors and Electronics,' California Management Review, 39(2), 8-41.

Hall, B. H. and R. Ham (1999), 'The Patent Paradox Revisited: Determinants of Patenting in the US Semiconductor Industry, 1980-1994,' NBER Working Paper 7062. NBER: Cambridge, MA.

Henderson, R. and K. Clark (1990), 'Architectural Innovation: The Reconfiguration of Existing Product Technologies and the Failure of Established Firms,' Administrative Science Quarterly, 35(1), 9-30.

Hounshell, D. A. and J. K. Smith (1988), Science and Strategy: DuPont RED, 1902-1980. Cambridge University Press: Cambridge. 
Iansiti, M. (1997), Technology Integration: Making Critical Choices in a Dynamic World. Harvard Business School Press: Boston, MA.

Iansiti, M. and J. West (1997), 'Technology Integration: Turning Great Research into Great Products,' Harvard Business Review, May/June, 69-79.

Klepper, S. (1996), 'Entry, Exit and Innovation over the Product Life Cycle,' American Economic Review, 86(3), 562-583.

Kline, S. J. and N. Rosenberg (1986), 'An Overview of Innovation,' in R. Landau and N. Rosenberg (eds), The Positive Sum Strategy. Harnessing Technology for Economic Growth. The National Academy Press: Washington, DC.

Kogut, B. and U. Zander (1993), 'Knowledge of the Firm and the Evolutionary Theory of the Multinational Corporation,' Journal of International Business Studies, 24, 625-645.

Kortum, S. and J. Lerner (1999), 'What is Behind the Recent Surge in Patenting,' Research Policy, 28, 1-22.

Lamoreaux, N. and K. Sokoloff (1997), 'Location and Technological Change in the American Glass Industry during the Late Nineteenth and Early Twentieth Centuries,' NBER Working Paper 5938. NBER: Cambridge, MA.

Lamoreaux, N. and K. Sokoloff(1998), 'Inventors, Firms, and the Market for Technology: US Manufacturing in the Late Nineteenth and Early Twentieth Centuries,' in N. Lamoreaux, D. Raff and P. Temin (eds), Learning by Firms, Organizations, and Nations. University of Chicago Press: Chicago, IL.

Lazonick, W. (1991), Business Organization and the Myth of the Market Economy. Cambridge University Press: Cambridge.

Lev, B. and P. Zarowin (1999), 'The Boundaries of Financial Reporting and How to Extend Them,' Journal of Accounting Research, 37(2), 353-386.

Levin, R. C., A. K. Klevorick, R. R. Nelson and S. G. Winter (1987), 'Appropriating the Returns from Industrial R\&D,' Brookings Papers on Economc Activity, 14, 551-561.

Levinthal, D. A. and J. G. March (1993), 'The Myopia of Learning,' Strategic Management Journal, 14, $95-112$.

Linden, G. and D. Somaya (1999), 'System-on-a-Chip Integration in the Semiconductor Industry: Industry Structure and Firm Strategies,' draft, University of California: Berkeley, CA.

Malerba, F. and L. Orsenigo (2000), 'Knowledge, Innovative Activities, and Industrial Evolution,' Industrial and Corporate Change, 3(2), 289-313.

March, J. G. (1991), 'Exploration and Exploitation in Organizational Learning,' Organization Science, 2, $71-87$.

Markides, C. C. and P. J. Williamson (1996), 'Corporate Diversification and Organization Structure: A Resource-based View,' Academy of Management Journal, 39, 340-367.

Mazzoleni, R. and R. R. Nelson (1998), 'The Benefits and Costs of Strong Patent Protection: A Contribution to the Current Debate,' Research Policy, 27(3), 275-286.

Merges, R. (1998), 'Intellectual Property Rights, Input Markets, and the Value of Intangible Assets,' mimeo. University of California Berkeley School of Law: Berkeley, CA.

Mowery, D. (1984), 'Firm Structure, Government Policy, and the Organization of Industrial Research,' Business History Review, 58, 504-531.

Nelson, R. R. (1959), 'The Simple Economics of Basic Scientific Research,' Journal of Political Economy, 67(2), 297-306.

Nelson, R. R. and S. Winter (1982), An Evolutionary Theory of Economic Change. Belknap Press: Cambridge, MA.

Pavitt, K. (2000), 'Specialisation and the Boundaries of the Firm,' mimeo. SPRU: Brighton.

Penrose, E. T. (1959), The Theory of Growth of the Firm. Blackwell: Oxford. 
Peteraf, M. A. (1993), 'The Cornerstones of Competitive Advantage: A Resource-based View,' Strategic Management Journal, 14(3), 179-191.

Pisano, G. P. (1990), 'The R\&D Boundaries of the Firm: An Empirical Analysis,' Administrative Science Quarterly, 35, 153-176.

Porter, M. (1998), 'Clusters and the New Economics of Competition,' Harvard Business Review, Nov/Dec, 77-90.

Rivette, K. G. and D. Kline (1999), Rembrandt in the Attic: Unlocking the Hidden Value of Patents. Harvard Business School Press: Boston, MA.

Rotemberg, J. J. and G. Saloner (1994), 'Benefits of Narrow Business Strategies' American Economic Review, 84(5), 1330-1349.

Shane, S. A. (1996), 'Hybrid Organizational Arrangements and their Implications for Firm Growth and Survival: A Study of New Franchisors,' Academy of Management Journal, 39(1), 216-234.

Stiglitz, J. E. and A. Weiss (1981), 'Credit Rationing in Markets with Imperfect Information,' American Economic Review, 71(3), 393-410.

Teece, D. J. (1986), 'Profiting from Technological Innovation. Implications for Integration, Collaboration, Licensing and Public Policy,' Research Policy, 15(6), 285-305.

Teece, D. J. (1988), 'Technological Change and the Nature of the Firm,' in G. Dosi et al. (eds), Technical Change and Economic Theory. Pinter: London.

Teece, D. J. (1998), 'Capturing Value from Knowledge Assets: The New Economy, Markets for Know-How, and Intangible Assets,' California Management Review, 40(3), 55-79.

Teece, D. J., G. Pisano and A. Shuen (1997), 'Dynamic Capabilities and Strategic Management,' Strategic Management Journal, 18, 509-533.

US Department of Justice (1995), Antitrust Guidelines for the Licensing of IP. US Department of Justice and Federal Trade Commission: Washington, DC.

von Hippel, E. (1990), 'Task Partitioning: An Innovation Process Variable,' Research Policy, 19, 407-418.

von Hippel, E. (1994), “'Sticky Information” and the Locus of Problem Solving: Implications for Innovation,' Management Science, 40(4), 429-439.

von Hippel, E. (1998), 'Economics of Product Development by Users: The Impact of "Sticky" Local Information,' Management Science, 44(5), 629-643.

Williamson, O. E. (1991), 'Comparative Economic Organization-The Analysis of Discrete Structural Alternatives,' Administrative Science Quarterly, 36(4), 269-296.

Winter, S. (1987), 'Knowledge and Competence as Strategic Assets,' in D. J. Teece (ed.), The Competitive Challenge: Strategies for Industrial Innovation and Renewal. Harper and Row: New York. 